\title{
Development and Evaluation of Antidiabetic Potential of Polyherbal Formulation in Streptozotocin Induced Animal Model
}

\author{
Mahendra Kumar Sahu*, Vijay Kumar Singh and S Prakash Rao \\ Columbia Institute of Pharmacy, India
}

Submission: August 08, 2018; Published: September 14, 2018

*Corresponding author: Mahendra Kumar Sahu, Department of Pharmacology, Columbia Institute of Pharmacy, Vill-Tekari, Near Vidhansabha, Raipur, Chhattisgarh, India; Tel: +91-8109794919; Email: mahendrapharma0310@gmail.com

\begin{abstract}
Background: Diabetes mellitus (DM) is a group of disorders that results in too much sugar in the blood due to impairment of lipids, carbohydrates, proteins metabolism.
\end{abstract}

Aim and objectives: Development and Evaluation of Polyherbal formulation (PHF) and determination of antidiabetic potential of developed formulation in Streptozotocin induced animal model.

Method: In the present study plant parts Azadirechta indica (AI) leaves, Moringa Oleifera (MO) fruits and Andrographis paniculata (AP) root and stem were collected and evaluated as per physico-chemical parameters and active chemical constituents were extracted using hydroalcoholic solvent. The active compounds present in all the three extracts were identified by preliminary phytochemical screening. PHF was prepared in a ratio of 1:1:1 quality of the finished product was evaluated on the parameter's angle of repose, loose bulk density, tapped bulk density, carr's index and hausner ratio as per the World Health Organization's (WHO) guidelines for the quality control of herbal materials. The acute toxicity study of PHF were performed as per OECD guideline 423, rats were orally administered 250, 500, 1000 and 2000mg/kg over 14 days. The oral glucose tolerance test (OGTT) was performed at 200 and $400 \mathrm{mg} / \mathrm{kg}$ body weight. Antidiabetic activity of the PHF (200 and $400 \mathrm{mg} / \mathrm{kg})$ was screened against streptozotocin (STZ) induced diabetes in rats and glibenclamide was used $(5.0 \mathrm{mg} / \mathrm{kg}$ body weight) as standard drug. The investigational drug was administered for 14 days and the effect of the PHF on blood glucose levels was studied at 14th day after interventional period. At the end of the study, the blood samples were collected from all the animals for biochemical estimation.

Result: The plant parts AI leaves, MO fruits, AP stem and leaves were evaluated as per physicochemical parameters and they were found as per API. Preliminary phytochemical screening of hydroalcoholic extracts were revealed that presence of alkaloids, glycosides, saponins, flavonoids, carbohydrates, steroids, tannins and phenolic compounds in each extract. PHF were developed by mixing of each extract in the same ratio and evaluated. It was found to be angle of repose $(\theta) 29.1$, loose bulk density $0.48 \mathrm{gm} / \mathrm{ml}$, tapped density $0.54 \mathrm{gm} / \mathrm{ml}$, carrs index $12.50 \%$, hausner's ratio 1.13. Diabetes was induced by STZ and treated with PHF did not show any change in behavior and no mortality was observed during interventional period upto the dose level $2000 \mathrm{mg} / \mathrm{kg}$. OGTT was performed by oral administration of PHF with dose $200 \mathrm{and} 400 \mathrm{mg} /$ $\mathrm{kg}$ body weight result was found to be gradually decreased in blood glucose level $75.75 \pm 1.92 \mathrm{mg} / \mathrm{dl}$ and $72 \pm 2.73 \mathrm{mg} / \mathrm{dl}$ at $180 \mathrm{~min}$ from the study it was predicted that PHF possess Anti-hyperglycemic activity. Experimental study was shows that on repeated administration of PHF and glibenclamide for 14 days, a sustained and significant decrease in the average blood glucose level of diabetic rats was observed. End of the interventional period biochemical parameters were studied, and it was found to be level of SGOT and urea level remain constant at dose of $200 \mathrm{mg} / \mathrm{kg}$, decrease in SGPT is near to standard and decrease in creatinine level is greater than Std at dose of $400 \mathrm{mg} / \mathrm{kg}$.

Conclusion: PHF containing extracts of (Azadirecta indica, Moringa oeifera and Andrographis paniculata) showed significant antidiabetic and antihyperlipidemic activity which was close to standard drug. Along with remarkable reduction in Total Cholesterol (TC) level and increased in High Density Lipoprotein (HDL) STZ induced diabetes rats. The formulation has emerged as potential combination which can challenge the synthetic drug.

Keywords: Diabetes mellitus; Azadirechta indica; Moringa oleifera; Andrographis paniculate; Polyherbal formulation, Glibenclamide

\section{Introduction}

\section{Importance of herbal in mankind}

Herbal drugs play an important role in the development of potent therapeutic agents. Furthermore, it has proven their potential for the prevention of several ailments. Earlier human beings started their studies on diseases and its treatments, but there was no evidence found that people have prehistoric use of synthetic medicines for their sickness [1]. However, they struggled to make use of the things, which could easily procure. The most common thing was found in their surrounding was 
plants and animals. Several plants were found suitable as a food supplement; some were poisonous and have medicinal importance [2]. Keeping this information in consideration, herbs were transferred from their origin to generation as folk medicine. So, the herbal medicine was known from ancient times. This is only because of the belief that many herbal medicines are known to be free from side effects. Furthermore, it is fact that the discovery of the new synthetic drug is time consuming \& an expensive. In the present scenario, the demand for herbal products is growing exponentially. All over the world pharmaceutical companies are currently conducting extensive research on plant materials for their probable medicinal value [3]. Research needs in the field of herbal medicines are enormous; the identification of active compounds from the plants source is still remaining a challenge. So, there should be research-based confirmation on either whole herbs or extracted compounds are superior. The issue of herb-herb and herb-drug interactions is also an important issue, which requires increased awareness and study, as polypharmacy and polyherbacy are common. The new technologies, such as nanotechnology and novel emulsification methods are used in the formulation of herbal products, which mainly affect bioavailability and the efficacy of herbal components and this also needs study. This can lead to reinvestigation of some agents that failed earlier trials and can be restudied and redesigned using new technologies to determine whether they can be modified for better efficacy and fewer side effects [4]. Today, there is an urgent need to develop safer drugs for the treatment of various disorders. As a result, there is a growing interest in the pharmacological evaluation of various plants used in traditional systems of medicine [5].

\section{Diabetes mellitus}

Diabetes Mellitus (DM) is a metabolic disorder associated by impairment in the metabolism of carbohydrate, fat and proteins which was recognized by insufficient insulin secretion or mounting resistance to its action [6]. DM develops due to obesity which is also an increasing problem worldwide, Induces atherosclerosis and other metabolic syndromes [69]. According to the requirements of insulin DM was classified into two main categories; insulin dependent diabetes mellitus (Type 1), and non-insulin dependent diabetes mellitus (Type 2) [10]. Which were proposed by WHO in 1980 and 1985 changed new classification system were identified four types of diabetes mellitus, Type 1 insulin dependent diabetes mellitus, Type 2 non-insulin dependent diabetes mellitus and Type 3 is Maturity Onset Diabetes of the Young (MODY) as well as Gestational Diabetes Mellitus (GDM) was classified as Type 4 [11].

\section{Materials and Methods}

\section{Drug and chemicals used}

Glibenclamide (USV Pharma Ltd. India), Straptozotocin (Lab chemicals, India), one touch glucometer (Johnson \& Johnson, India), Ethanol (Qualigens, India) and other chemicals were used of analytical grade.

\section{Collection, identification and authentification of plant materials}

In the present study, the fresh leaves of Azadirechta indica, fruits of Moringa oleifera and fresh leaves and roots of Andrographis paniculata were collected in febuary, 2018, from Raipur, Chhattisgarh, India. The plants were identified and authenticated by Dr. S. Prakash Rao, Department of Phytochemistry and Pharmacognosy, Columbia Institute of Pharmacy, Raipur, Chhattisgarh, India.

\section{Quality assessment/Physiochemical evaluation of plant materials}

Each plant parts were crushed and converted into fine powders than quality assessment of plant materials was done as per the standard procedure of Ayurvedic Pharmacopeia of India. Different parameters were tested with the methods describe in API.

a. Foreign organic matter: According to Ayurvedic Pharmacopeia of India, Foreign matter is described as any material that consist of part of organ or organ part from which the drug is derived. The plant should be free from any foreign particle like dust, insects, faecal matter etc. The percentage of foreign matter should not be more than the limit prescribed in monograph. There should not be any contamination in drug material used for developing the polyherbal formulation (PHF).

b. Procedure: 100-500gm of plant materials were weighed and spread as a thin layer and was inspected first with naked eyes and then with the use of lens (6x). All the foreign matter was

c. Separated, weighed and percentage was calculated.

d. Determination of total ash value: $3 \mathrm{gm}$ of dried powered sample was weighed in silica dish and it was incinerated at a temperature not exceeding $450{ }^{\circ} \mathrm{C}$ until it gets free from carbon. The incinerated material was cooled, weighed and percentage of ash was calculated with reference to air dried drug.

e. Determination of acid insoluble ash value: Ash obtained was boiled with $25 \mathrm{ml}$ of dil. HCL for 5 minutes filtered and insoluble matter was collected in crucible and washed with hot water and ignited till constant weight. The percentage of acid insoluble ash was calculated with respect to air dried drug.

f. Determination of alcohol soluble extractive value: $5 \mathrm{gm}$ of powdered drug was macerated with $100 \mathrm{ml}$ of alcohol in cork fitted conical flask. Solution was shaken frequently for $6 \mathrm{hrs}$. and was allowed to stand for $18 \mathrm{hrs}$. After $18 \mathrm{hr}$. content was filtered and $25 \mathrm{ml}$ of filtrate was evaporated to dryness in a shallow dish at $105{ }^{\circ} \mathrm{C}$ to constant weight and percentage of alcohol soluble extractives was calculated with reference to air dried drug. 
g. Determination of water-soluble extractives: $5 \mathrm{gm}$ of powdered drug was macerated with $100 \mathrm{ml}$ of water in cork fitted conical flask. Solution was shaken frequently for $6 \mathrm{hrs}$ and allowed to stand for $18 \mathrm{hrs}$. After $18 \mathrm{hr}$. content was filtered, and $25 \mathrm{ml}$ of filtrate was evaporated to dryness in a shallow dish at $105^{\circ} \mathrm{C}$ to constant weight and percentage of water soluble extractives was calculated with reference to air dried drug. The data generated in respect of above findings will be used as in-house standards.

\section{Preparation of hydro-alcoholic (HA) extracts}

The plant parts were washed, shade dried and powdered. In order to prepare the PHF, about 500gm of Azadirecta Indica (leaves), 500gm of Moringa Oleifera (fruits) and 500gm of Andrographis paniculata (roots and leaves) powders were Table 1: Preliminary phytochemical screening of HA extracts. soaked overnight separately in 1000-1200ml of Petroleum Ether (PE). After 3 days the suspension was filtered and PE was to be evaporated overnight. Again, the dried powders were separately resuspended in a Stoppered container with the HA solvent. Allowed to stand at room temperature for a period of 7 days. Additionally, extract was concentrated to dryness in a rotary evaporator (Buchi type) under reduced pressure and controlled temperature $\left(37-40^{\circ} \mathrm{C}\right)$ to get percentage yield.

Preliminary phytochemical screening of HA extracts: Crude extract of plants was subjected to different chemical tests to detect the presence of various phytochemical constituents as per procedure adopted in literature by Madhav and Saha. The details are incorporated below in the following Table 1. Results of the entire chemical test are discussed in Results.

\begin{tabular}{|c|c|c|c|c|c|}
\hline Constituent & Chemical Test & Procedure & Azadirechta Indica & Moringa Oleifera & $\begin{array}{l}\text { Andrographis } \\
\text { Paniculata }\end{array}$ \\
\hline \multirow{2}{*}{ Alkaloids } & $\begin{array}{c}\text { Mayer's reagent } \\
\text { test }\end{array}$ & $\begin{array}{l}\text { Extract+ Dil. HCL }+3 \mathrm{ml} \\
\text { Mayer's reagent }\end{array}$ & $\begin{array}{c}\text { Yellow precipitate } \\
\text { obtained }\end{array}$ & $\begin{array}{c}\text { Yellow precipitate } \\
\text { obtained }\end{array}$ & $\begin{array}{c}\text { Yellow precipitate } \\
\text { obtained }\end{array}$ \\
\hline & $\begin{array}{l}\text { Dragondroff's } \\
\text { test }\end{array}$ & $\begin{array}{l}\text { Extract }+ \text { Dil. HCL }+3 \mathrm{ml} \\
\text { Dragendroff's reagent }\end{array}$ & $\begin{array}{l}\text { Reddish brown } \\
\text { precipitate }\end{array}$ & $\begin{array}{l}\text { Reddish brown } \\
\text { precipitate }\end{array}$ & $\begin{array}{l}\text { Reddish brown } \\
\text { precipitate }\end{array}$ \\
\hline Glycosides & Legal's test & Extract $+10 \%$ & $\mathrm{NaoH}+$ Sodium & Nitroprusside & Blue colour \\
\hline \multirow[t]{2}{*}{ Saponins } & Flavonoids & $\begin{array}{c}\text { Foam test Extract + } \\
\text { water }\end{array}$ & shaken vigorously & Persistance & Foam \\
\hline & Lead acetate & test & Extract solution of & lead acetate & Yellow \\
\hline Carbohydrate's & Fehling's test & $\begin{array}{l}1 \mathrm{ml} \text { Fehling } \mathrm{A}+1 \mathrm{ml} \\
\text { Fehling mixed and } \\
\text { boiled for a minute }\end{array}$ & $\begin{array}{l}\text { Brick red precipitate } \\
\text { formed }\end{array}$ & $\begin{array}{l}\text { Brick red precipitate } \\
\text { formed }\end{array}$ & $\begin{array}{l}\text { Brick red precipitate } \\
\text { formed }\end{array}$ \\
\hline Steroid's & Salkowski test & $\begin{array}{c}\text { Extract }(2 \mathrm{ml}) \\
+2 \mathrm{ml}+\text { chloroform }+2 \mathrm{ml} \\
\text { conc. } \mathrm{H}_{2} \mathrm{SO}_{4}\end{array}$ & $\begin{array}{l}\text { Chloroform layer } \\
\text { turned red and acid } \\
\text { layer green }\end{array}$ & $\begin{array}{l}\text { Chloroform layer } \\
\text { turned red and acid } \\
\text { layer green }\end{array}$ & $\begin{array}{c}\text { No Chloroform layer } \\
\text { Formed }\end{array}$ \\
\hline $\begin{array}{l}\text { Tannin's and Phenolic } \\
\text { Compounds }\end{array}$ & $\mathrm{FeCl}_{3}$ test & Extract $+\mathrm{FeCl}_{3}$ & Deep blue Coloured & Deep blue Coloured & Deep blue Coloured \\
\hline
\end{tabular}

\section{Design and development of PHF}

From the extracts of three plants Azadirechta indica (leaves), Moringa Oleifera (fruits) and Andrographis paniculata (roots and leaves), formulation have been made by blending the extracts in ration $1: 1: 1$.

\section{Evaluation of polyherbal formulations}

Prepared PHF was evaluated on following parameters:

\section{a. Angle of repose}

Angle of repose was determined by using funnel method. The accurately weighed blend was taken in a funnel. The height of the funnel was adjusted in such a way that the tip of the funnel just touches the apex of the heap or head of blend. The drug excipient blend was allowed to flow through the funnel freely on to the surface. The diameter of the powder cone was measured, and angle of repose was calculated using the following equation:

\section{$\tan \theta=\mathrm{h} / \mathrm{r}$}

Where, $\mathrm{h}=$ height of powder cone formed, $\mathrm{r}=$ radius of the powder cone formed

\section{b. Loose bulk density}

Apparent bulk density was determined by pouring a weighed quantity of blend into graduated

cylinder and measuring the volume and weight.

LBD $=$ Weight of the powder/volume of the packing

\section{c. Tapped bulk density}

It was determined by placing a graduated cylinder, containing a known mass of drug excipient blend. The cylinder was allowed to fall under its own weight on to a hard surface from the height of $10 \mathrm{~cm}$ at two second intervals. The tapping was continued until no further change in volume was noted.

TBD = Weight of the powder/vol of the tapped packing

\section{d. Compressibility index}

The Compressibility index of the blends was determined by Carr's compressibility index.

Compressibility index $(\%)=($ TBD-LBD $) \times 100 / T B D$ 


\section{International Journal of Cell Science \& Molecular Biology}

\section{e. Hausner ratio}

It is the measurement of frictional resistance of drug and ideal range should be $1.2-1.5$. It is determined by using the following formula:

Hausner ratio $=$ TBD $/$ LBD

\section{Acute toxicity study of PHF as per OECD guidelines}

Preparation of formulations: For dosing $100 \mathrm{ml}$ of each formulation was prepared by dissolving $5 \mathrm{gm}$ of formulation in $100 \mathrm{ml}$ of distilled water (so, $1 \mathrm{ml}$ contain $50 \mathrm{mg}$ of drug).

Experimental animals: Adult Wistar rats $(180 \pm 10 \mathrm{~g})$ of either sex were obtained from Columbia institute of pharmacy, Raipur, Chhattisgarh, india. The animals were housed in large, spacious polyacrylic cages at an ambient room temperature with $12 \mathrm{~h}$ light $/ 12 \mathrm{~h}$ dark cycle. Rats had free access to water and rodent pellets diet (Hindustan Lever Ltd, Bangalore, India). The study was approved by the Institute Animal Ethics Committee and all the animal experiments were carried out according to the Committee for the Purpose of Control and Supervision of Experiments on Animals (CPCSEA) guidelines, Regd. No. 1321/ $\mathrm{PO} / \mathrm{ReBi} / \mathrm{S} / 10 / 10 / \mathrm{CPCSEA}$.

Acute toxicity study of PHF: Acute toxicity studies were carried out in adult female albino rats weighing between 130 $180 \mathrm{gm}$ by Acute Oral Toxicity method of OECD Guideline No 423. They were administered (orally) with varying doses (250, 500, 1000 and $2000 \mathrm{mg} / \mathrm{kg}$ body weight) for each of six formulations. Animals were divided into 5 groups of three animals each and were acclimatized for 5 days. Prior to dosing animals were kept fasted overnight and next day each formulation were administered orally at a dose level of 250, 500, 1000 and $2000 \mathrm{mg} / \mathrm{kg}$ body weight. Rats were observed for clinical signs of toxicity continuously for 2 hours and occasionally for further 4 hours for general behavioral and finally for any mortality after 24 hours till 14 days. No mortality was observed during a time period of 14 days.

\section{Oral glucose tolerance test of formulation}

Selection of dose: Two dose level were chosen in such a way that one dose was approximately one-tenth of the maximum dose used during the acute toxicity studies, second dose was the twice that of one tenth dose $(200 \mathrm{mg} / \mathrm{kg}, 400 \mathrm{mg} / \mathrm{kg} \mathrm{b.wt})$

Initial Screening of all the PHF for anti-hyperglycemic activity (oral glucose tolerance test): Formulation was screened for anti-hyperglycemic activity to get the information on their efficacy so that the formulation which is not effective could be modified. Formulation was analysed for antihyperglycemic and antihyperlipidemic activity in normal healthy rats by conducting Oral Glucose Tolerance Test (OGTT). Initial testing was carried out at different dose levels of formulation (200 and $400 \mathrm{mg} / \mathrm{kg} \mathrm{b.} \mathrm{wt).} \mathrm{Overnight} \mathrm{fasted} \mathrm{rats} \mathrm{were} \mathrm{weighed}$ and divided in to five groups with 5 rats in each group for each formulation as given below. After 30 minutes, rats of all groups were loaded orally with glucose $2 \mathrm{~g} / \mathrm{kg}$ b. wt. Blood glucose level was determined by glucometer before and at $30 \mathrm{~min}, 60 \mathrm{~min}$, $120 \mathrm{~min}, 150 \mathrm{~min}$ and $180 \mathrm{~min}$ after loading with glucose.

\section{Group Design for OGTT study:}

Group I - Normal Control treated with vehicle i.e. $(2 \mathrm{ml} / \mathrm{kg})$ distilled water

Group II- Standard given Glibenclamide (5mg/b. wt)

Group III- treated orally with F-A $200 \mathrm{mg} / \mathrm{kg}$ b.wt.

Group IV- treated orally with F-A 400mg/kg b.wt.

\section{Antidiabetic activity}

Study protocol: Induction of diabetes and experimental study Diabetes was induced in rats by intra-peritoneal injection of Streptozotocin ( $45 \mathrm{mg} / \mathrm{kg} \mathrm{b.} \mathrm{wt)}$ which was dissolved in normal saline. After $72 \mathrm{~h}$ of STZ administration blood glucose level was measured by one touch glucometer (Johnson \& Johnson, India) to confirm diabetes. Blood samples were drawn by picking the rat tail. The diabetic rats with blood glucose levels $\geq 250 \mathrm{mg} / \mathrm{dl}$ were selected for the studies. After $72 \mathrm{hr}$. of STZ injection animal with $B G L \geq 250 \mathrm{mg} / \mathrm{dl}$ were divided into different groups (with 5 animals each) for anti-diabetic study of Formulations. Following groups were prepared:

Group I -Normal control (given distilled water)

Group II-Negative control (treated with STZ $45 \mathrm{mg} / \mathrm{kg}$ b. wt i.p)

Group III-Standard (Treated with Glibenclamide $5 \mathrm{mg} / \mathrm{kg}$ b. wt after $3^{\text {rd }}$ day of STZ injection)

Group IV-Treated orally with Formulation A with dose of $200 \mathrm{mg} / \mathrm{kg}$ b. wt after $3^{\text {rd }}$ day of STZ injection

Group V- Treated orally with Formulation A dose of 400mg/ $\mathrm{kg}$ b. wt after $3^{\text {rd }}$ day of STZ injection

Study was conducted for 14 days. Treatment was started from $3^{\text {rd }}$ day. Standard drug and Formulations given daily for 14 days and blood glucose levels were measured with the help of one touch glucometer (Johnson \& Johnson, India) on $3^{\text {rd }}$ day (assume as $0 \mathrm{hrs}$. ), after $3 \mathrm{hrs} .5^{\text {th }}$ day, $10^{\text {th }}$ day and $14^{\text {th }}$ day of experiment. Blood sample was taken by picking the rat tail vein and for the measurement of other biochemical parameters blood sample was withdrawn from retro orbital plexus of rats.

Assessment of Biochemical parameters: At the end of $14^{\text {th }}$ day of experiment, $2-4 \mathrm{ml}$ blood sample was withdrawn from retro-orbital plexus of rats and centrifuged at the 5000rpm for 15-20min; serum was separated and taken out with the help of syringe. Serum of rats was used for the analysis of other biochemical parameters through Auto analyser.

\section{Results and Observation}

\section{Physiochemical evaluation of plant materials}

It was observed that all physicochemical evaluation parameters contain i.e. foreign organic matter, Total ash, Acid 
insoluble ash, Alcohol extractive and water-soluble extractives of plant drug was found to be within Ayurvedic pharmacopeia

limits Table 2.

Table 2: Results of Physico-chemical evaluation of the plant material.

\begin{tabular}{|c|c|c|c|c|c|c|}
\hline \multirow{2}{*}{ Parameter } & \multicolumn{2}{|c|}{ Azadirecta indica } & \multicolumn{2}{c|}{ Moringa Oleifera } & \multicolumn{2}{c|}{ Andrographis paniculata } \\
\cline { 2 - 7 } & Obtained value & API limit & Obtained value & API limit & Obtained value & API limit \\
\hline Foreign organic matter & $0.002 \%$ & NMT 0.3\% & $1.87 \pm .05 \%$ & NMT 2\% & $1.78 \pm 01 \%$ & NMT 2\% \\
\hline Total ash value & $3.48 \pm 23 \%$ & NMT 5\% & $4.36 \pm .22 \%$ & NMT 5\% & $1.55 \pm .25 \%$ & NMT $12 \%$ \\
\hline Acid insoluble ash value & $0.43 \pm .01 \%$ & NMT 0.6 $\%$ & $1.33 \pm .25 \%$ & NMT 2\% & $0.30 \pm .03 \%$ & NMT $0.5 \%$ \\
\hline Alcohol extractive value & $8.30 \pm 0.72 \%$ & NLT 6\% & $11.69 . \pm 54 \%$ & NMT 12\% & $9.59 \pm .36 \%$ & NLT 7\% \\
\hline Water soluble extractive value & $30.78 \pm 0.51 \%$ & NLT 28\% & $22.42 \pm .76 \%$ & NMT 23\% & $7.34 \pm .74 \%$ & NLT $5 \%$ \\
\hline
\end{tabular}

(NMT-Not more than, NLT -Not less than).

\section{Percentage yield of all the HA plant extracts}

The percentage yields of all HA plant extract are given in Table 3.

Table 3: Percentage yield of HA plant extracts.

\begin{tabular}{|c|c|c|c|}
\hline $\begin{array}{c}\text { Name of Plant } \\
\text { Drug }\end{array}$ & $\begin{array}{c}\text { Powdered Plant } \\
\text { Drug (gm) }\end{array}$ & $\begin{array}{c}\text { Solvent used } \\
\text { Ethanol: Water } \\
\mathbf{( 1 0 : 9 0 )}\end{array}$ & $\begin{array}{c}\text { Percentage } \\
\text { yield }\end{array}$ \\
\hline $\begin{array}{c}\text { Azadirechta } \\
\text { indica }\end{array}$ & $250 \mathrm{gm}$ & $1000 \mathrm{ml}$ & $11.00 \%$ \\
\hline $\begin{array}{c}\text { Moringa } \\
\text { Oleifera }\end{array}$ & $250 \mathrm{gm}$ & $1000 \mathrm{ml}$ & $24.09 \%$ \\
\hline $\begin{array}{c}\text { Andrographis } \\
\text { panichulata }\end{array}$ & $250 \mathrm{gm}$ & $1000 \mathrm{ml}$ & $15.23 \%$ \\
\hline
\end{tabular}

\section{Preliminary phytochemical screening of HA plant} extracts

Results of phytochemical screening are shown in Table 4. It was found that Azadirechta indica, Moringa Oleifera and Andrographis paniculata contain all tested phytochemical compounds.

Table 4: Preliminary Phytochemical screening of HA plant extract.

\begin{tabular}{|c|c|c|c|}
\hline Constituent & $\begin{array}{c}\text { Azadirechta } \\
\text { indica }\end{array}$ & $\begin{array}{c}\text { Moringa } \\
\text { Oleifera }\end{array}$ & $\begin{array}{c}\text { Andrographis } \\
\text { paniculata }\end{array}$ \\
\hline Alkaloids & + & + & - \\
\hline Glycosides & + & + & + \\
\hline Saponins & + & + & + \\
\hline Flavonoids & + & + & + \\
\hline Carbohydrate's & + & + & + \\
\hline Steroid's & + & + & + \\
\hline $\begin{array}{c}\text { Tannin's and Phenolic } \\
\text { Compounds }\end{array}$ & - & + & + \\
\hline
\end{tabular}

\section{Design and development of PHF}

PHF was made in such a way so that it covers most of targeted sites in body to decrease the blood glucose level for their anti-diabetic action. For formulations quantity of doses used in developing the formulation was calculated on the basis of therapeutic doses reported in literatures.
Evaluation of polyherbal formulations: The various combinations of dried powdered extracts of Azadirechta indica, Moringa Oleifera, Andrographis paniculata were prepared and evaluated on the parameters like angle of repose, loose bulk density, tapped bulk density, carr's index and hausner ratio. Preformulation study of the granules showed that all the evaluated parameters were within the acceptable limit Table 5.

Table 5: Evaluation parameters of dried PHF.

\begin{tabular}{|c|c|c|c|c|c|}
\hline Batch & $\begin{array}{c}\text { Angle of } \\
\text { repose }\end{array}$ & $\begin{array}{c}\text { Loose } \\
\text { bulk } \\
\text { density }\end{array}$ & $\begin{array}{c}\text { Tapped bulk } \\
\text { density }\end{array}$ & $\begin{array}{c}\text { Carr's } \\
\text { index }\end{array}$ & $\begin{array}{c}\text { Hausner's } \\
\text { ratio }\end{array}$ \\
\hline PHF & 29.1 & 0.48 & 0.54 & 12.5 & 1.13 \\
\hline
\end{tabular}

\section{Acute toxicity study of PHF formulation}

STZ induced diabetic rats treated with PHF did not show any discernible change in behaviour up to the dose level of $2000 \mathrm{mg} /$ kg body weight. No sign of mortality was observed during the observation of 14 days Table 6.

\section{Oral glucose tolerance test (OGTT) of PHF}

At $30 \mathrm{~min}$ after the administration of $2 \mathrm{gm} / \mathrm{kg}$ glucose orally, the plasma glucose level is significantly increased and the blood glucose level decreases gradually with the administration of formulations. Results are given in Table 6 and results expressed in Mean \pm SD in Table 7.

Findings of OGTT study: It was found that PHF with dose of $200 \mathrm{mg} / \mathrm{kg}$ body weight showed effective decrease in blood glucose i.e. $75.75 \pm 1.92 \mathrm{mg} / \mathrm{dl}$ and dose $400 \mathrm{mg}$ showed $72 \pm 2.73 \mathrm{mg} / \mathrm{dl}$ at $180 \mathrm{~min}$. From the study it was predicted that PHF possess Anti-hyperglycemic activity.

\section{Antidiabetic activity}

Experimental study: Albino wistar rats of either sex (150-180gm body weight) were used for this study; they were acclimatized and given proper diet. The study was approved by the Institute Animal Ethics Committee and all the animal experiments were carried out according to the Committee for the Purpose of Control and Supervision of Experiments on Animals (CPCSEA) guidelines. Results showed the significantly increase 
in blood glucose level in STZ treated diabetic rats. Glucose levels measured in blood of normal and experimental rats are given in Table 8. On repeated administration of vehicle, PHF and Table 6: Results of Toxicity study of Formulation. glibenclamide for 14 days, a sustained and significant decrease in the average blood glucose level of diabetic rats was observed.

\begin{tabular}{|c|c|c|c|c|c|}
\hline Group & No of rats & Wt. of rats (gm) & Dose of formulation & Calculated dose (mg) & No. of dead animals \\
\hline \multirow{3}{*}{ I } & \multirow{3}{*}{3} & 150.23 & \multirow{3}{*}{$250 \mathrm{mg} / \mathrm{kg}$ b. wt. } & 37.55 & \multirow{3}{*}{ Nil } \\
\hline & & 148.79 & & 37.19 & \\
\hline & & 150.12 & & 37.53 & \\
\hline \multirow{3}{*}{ II } & \multirow{3}{*}{3} & 151.4 & \multirow{3}{*}{$500 \mathrm{mg} / \mathrm{kg}$ b. wt. } & 75.7 & \multirow{3}{*}{ Nil } \\
\hline & & 145.62 & & 72.81 & \\
\hline & & 156.01 & & 78 & \\
\hline \multirow{3}{*}{ III } & \multirow{3}{*}{3} & 150.92 & \multirow{3}{*}{$1000 \mathrm{mg} / \mathrm{kg}$ b. wt. } & 150.92 & \multirow{3}{*}{ Nil } \\
\hline & & 150.12 & & 150.12 & \\
\hline & & 152.34 & & 150.34 & \\
\hline \multirow{3}{*}{ IV } & \multirow{3}{*}{3} & 155.03 & \multirow{3}{*}{$2000 \mathrm{mg} / \mathrm{kg}$ b. wt. } & 310.06 & \multirow{3}{*}{ Nil } \\
\hline & & 142.34 & & 284.68 & \\
\hline & & 145.73 & & 291.46 & \\
\hline
\end{tabular}

Table 7: Results of OGTT.

\begin{tabular}{|c|c|c|c|c|c|c|c|c|c|c|c|}
\hline \multirow[t]{2}{*}{ Group } & \multirow[t]{2}{*}{ Treatment } & \multirow{2}{*}{$\begin{array}{l}\text { No. of } \\
\text { rats }\end{array}$} & \multirow{2}{*}{$\begin{array}{l}\text { Weight of } \\
\text { rats (gm) }\end{array}$} & \multirow[t]{2}{*}{ Dose } & \multirow{2}{*}{$\begin{array}{l}\text { Calculated } \\
\text { dose }\end{array}$} & \multirow{2}{*}{$\begin{array}{l}\text { Fasting } \\
\text { BGL mg/dl }\end{array}$} & \multicolumn{5}{|c|}{$\begin{array}{l}\text { After loading with glucose } 2 \mathrm{~g} / \mathrm{kg} \text { b. wt. (Oral } \\
\text { Glucose Tolerance Test) }\end{array}$} \\
\hline & & & & & & & $30 \mathrm{~min}$ & $60 \mathrm{~min}$ & $120 \mathrm{~min}$ & $150 \mathrm{~min}$ & $180 \mathrm{~min}$ \\
\hline \multirow{5}{*}{ I } & \multirow{5}{*}{ Control } & \multirow{5}{*}{5} & 152.23 & \multirow{5}{*}{$\begin{array}{c}2 \mathrm{ml} / \mathrm{kg} \\
\text { b. wt }\end{array}$} & $0.30 \mathrm{ml}$ & 68 & 102 & 116 & 128 & 130 & 127 \\
\hline & & & 149.62 & & 0.29 & 69 & 99 & 110 & 118 & 127 & 123 \\
\hline & & & 155.24 & & 0.31 & 63 & 98 & 113 & 120 & 135 & 129 \\
\hline & & & 161.08 & & 0.32 & 60 & 95 & 120 & 127 & 142 & 135 \\
\hline & & & 153.12 & & 0.3 & 65 & 92 & 115 & 122 & 135 & 130 \\
\hline \multirow{5}{*}{ II } & \multirow{5}{*}{ Glibenclamide } & \multirow{5}{*}{5} & 149.58 & \multirow{5}{*}{$\begin{array}{c}5 \mathrm{mg} / \mathrm{kg} \\
\text { b. wt }\end{array}$} & $0.067 \mathrm{mg}$ & 64 & 98 & 86 & 75 & 71 & 62 \\
\hline & & & 151.32 & & 0.067 & 66 & 103 & 90 & 76 & 68 & 58 \\
\hline & & & 166.71 & & 0.075 & 60 & 104 & 89 & 79 & 69 & 58 \\
\hline & & & 168.54 & & 0.075 & 65 & 99 & 80 & 73 & 66 & 60 \\
\hline & & & 160.03 & & 0.072 & 67 & 107 & 91 & 79 & 65 & 61 \\
\hline \multirow{5}{*}{ III } & \multirow{5}{*}{ Fomulation } & \multirow{5}{*}{5} & 168.48 & \multirow{5}{*}{$\begin{array}{l}200 \mathrm{mg} / \\
\mathrm{kg} \text { b. wt }\end{array}$} & 33.69 & 67 & 103 & 89 & 90 & 78 & 76 \\
\hline & & & 162.72 & & 32.54 & 69 & 110 & 108 & 95 & 79 & 75 \\
\hline & & & 154.13 & & 30.82 & 71 & 111 & 111 & 99 & 82 & 74 \\
\hline & & & 150.34 & & 30.06 & 69 & 107 & 86 & 93 & 76 & 79 \\
\hline & & & 152.16 & & 30.43 & 70 & 103 & 91 & 89 & 81 & 75 \\
\hline \multirow{5}{*}{ IV } & \multirow{5}{*}{ Formulation } & \multirow{5}{*}{5} & 170.02 & \multirow{5}{*}{$\begin{array}{l}400 \mathrm{mg} / \\
\mathrm{kg} \text { b. wt }\end{array}$} & 68 & 60 & 100 & 95 & 85 & 80 & 78 \\
\hline & & & 148.53 & & 59.41 & 61 & 105 & 97 & 79 & 76 & 60 \\
\hline & & & 156.61 & & 62.64 & 63 & 99 & 87 & 79 & 72 & 68 \\
\hline & & & 157.09 & & 62.83 & 66 & 95 & 89 & 84 & 80 & 76 \\
\hline & & & 162.08 & & 64.83 & 60 & 108 & 96 & 86 & 79 & 80 \\
\hline
\end{tabular}

Biochemical parameters: Serum TG, Total cholesterol, LDL cholesterol were found to be increased significantly $(\mathrm{P}<0.0001)$ in STZ induced diabetic rats (shown in Table 9) as compared to non-diabetic control. HDL cholesterol was found to be significantly decreased in diabetic rats. Treatment with PHF produces a significant reduction in elevated serum TG, TC, LDL-cholesterol level in diabetic rats. In Biochemical Parameters
PHF (400mg and 200mg) showed maximum decrease in SGPT, Urea and LDL Cholesterol level i.e. 69.8\% near to glibenclamide, $43.36 \%$ and $39.6 \%$ Table 10 .

\section{Discussion}

PHF have been developed with combinations of (3 Plants) antidiabetic activity was investigated in albino wistar rats with 
glibenclamide as standard, STZ was used to induce diabetes in rats. Formulation showed significant decrease in Blood glucose level with improvement in slight loss of body weight, Albino wistar rats were divided into $V$ groups with $n=5$ and the diabetic rats received the formulation, vehicle and standard drug. Although formulation showed good antidiabetic activity. It showed $65.8 \%$ decrease in average blood glucose level which was very closer to standard drug glibenclamide. i.e. 66.2\%. Reason for this superior activity of Formulation may be its potential active constituents which could possess better antidiabetic activity and the second main reason may its synergism (herb-herb interactions) which may be more compatible when formulated together and thus produce more effective results. As mentioned in results all the formulations give dose dependent antidiabetic effect in this combination of medicinal plants. It was proved to be fruitful and comparable to standard against glibenclamide. PHF showed good antidiabetic activity with dose of $400 \mathrm{mg}$ (i.e. $62.4 \%$ ) decrease in blood glucose level. On the basis of best synergistic effect, the lipid content except HDL was found to be increased in STZ diabetic rats. HDL Cholesterol was found to be more increased in combination as compared to individual. All combinations improve the conditions of hypercholesterolemia. PHF showed a greater increase in HDL \% level to $57.12 \%$ than those of standard. It has been observed through literatures that plants constituents like glycosides, alkaloids, flavonoids all these constituents have proved to be strong antidiabetic agent through different mechanism.

Table 8: Average OGTT (Blood glucose level expressed in Mean \pm S.E.).

\begin{tabular}{|c|c|c|c|c|c|c|c|}
\hline Group & Treatment & Fasting BGL & $\mathbf{3 0 m i n}$ & $\mathbf{6 0 m i n}$ & $\mathbf{1 2 0} \mathbf{m i n}$ & $\mathbf{1 5 0} \mathbf{m i n}$ & $\mathbf{1 8 0} \mathbf{m i n}$ \\
\hline I & Control & $65.0 \pm 3.67$ & $81.63 \pm 3.83$ & $96.28 \pm 3.70$ & $103.22 \pm 4.35$ & $112.45 \pm 5.71$ & $128.8 \pm 4.38$ \\
\hline II & Glibenclamide & $64.40 \pm 2.70$ & $102.2 \pm 3.70$ & $87.2 \pm 4.43$ & $76.4 \pm 2.60$ & $67.8 \pm 2.38$ & $59.8 \pm 1.78$ \\
\hline III & Formulation & $69.2 \pm 1.48$ & $106.8 \pm 3.76$ & $94.4 \pm 4.97$ & $93.2 \pm 4.02$ & $79.2 \pm 2.38$ & $75.75 \pm 1.92$ \\
\hline IV & Formulation & $62.0 \pm 2.54$ & $99.4 \pm 3.64$ & $92.8 \pm 4.49$ & $82.6 \pm 3.36$ & $77.4 \pm 3.43$ & $72.0 \pm 2.73$ \\
\hline
\end{tabular}

Table 9: Effect of PHF on change in biochemical parameters of blood plasma in albino wistar rats from 0th day to $14^{\text {th }}$ day.

\begin{tabular}{|c|c|c|c|c|c|c|c|c|c|c|}
\hline \multirow[b]{2}{*}{ Parameters } & \multicolumn{2}{|c|}{ Group I (Control) } & \multicolumn{2}{|c|}{ Group II (Negative control) } & \multicolumn{2}{|c|}{ Group III (Standard) } & \multicolumn{2}{|c|}{ Group IV 200mg } & \multicolumn{2}{|c|}{ Group V 400mg } \\
\hline & $0^{\text {th }}$ day & $\begin{array}{l}\text { After } 15^{\text {th }} \\
\text { day }\end{array}$ & $0^{\text {th }}$ day & After $15^{\text {th }}$ day & $0^{\text {th }}$ day & $\begin{array}{l}\text { After } 15^{\text {th }} \\
\text { day }\end{array}$ & $0^{\text {th }}$ day & $\begin{array}{c}\text { After } \\
\mathbf{1 5}^{\text {th }} \text { day }\end{array}$ & $0^{\text {th }}$ day & $\begin{array}{l}\text { After } 15^{\text {th }} \\
\text { day }\end{array}$ \\
\hline \multirow{5}{*}{ Cholesterol } & 47.5 & 50.7 & 85.6 & 95.9 & 113.4 & 58.4 & 96.4 & 78.2 & 84.5 & 49.3 \\
\hline & 48.7 & 49 & 91.6 & 112.6 & 96.7 & 48.3 & 120.4 & 91.3 & 93.9 & 58.6 \\
\hline & 55 & 60.2 & 98.4 & 126.4 & 126.5 & 49.4 & 98.9 & 71.7 & 117.8 & 80.8 \\
\hline & 50.3 & 48.1 & 88.2 & 102.4 & 109.4 & 46.7 & 104.4 & 79.4 & 111.9 & 72.9 \\
\hline & 62 & 55.3 & 112.4 & 126.6 & 89.4 & 38.7 & 85.6 & 59.2 & 107.8 & 66.6 \\
\hline \multirow{5}{*}{ Triglycerides } & 59.8 & 61.7 & 166 & 212.9 & 155.2 & 71.2 & 125.3 & 79.5 & 115.7 & 64.5 \\
\hline & 76.2 & 80.4 & 97 & 140.2 & 93.4 & 49.6 & 134.2 & 99.16 & 96.9 & 46.8 \\
\hline & 60.4 & 60.9 & 113.8 & 143.8 & 133.4 & 73.5 & 128.7 & 93.1 & 129.5 & 77.8 \\
\hline & 68.6 & 69.9 & 99.2 & 124.5 & 148.9 & 70.5 & 106.8 & 75.7 & 133.7 & 84.4 \\
\hline & 68.4 & 67.6 & 84.3 & 111.7 & 138.6 & 67.3 & 112.4 & 78.8 & 118.9 & 64.6 \\
\hline \multirow{5}{*}{ SGOT } & 10.8 & 11.2 & 68.2 & 72.3 & 49.1 & 15.2 & 50.3 & 30.2 & 56.7 & 25.4 \\
\hline & 25.2 & 26.7 & 59.5 & 74.6 & 63.2 & 20.2 & 47.6 & 18.3 & 45.2 & 20 \\
\hline & 20.5 & 11.4 & 52.6 & 62 & 58.4 & 26.3 & 49.2 & 21.4 & 43.8 & 16.3 \\
\hline & 31.6 & 30.2 & 49 & 60.1 & 41.8 & 13.1 & 60.4 & 39.2 & 58.4 & 18.4 \\
\hline & 13.7 & 18.2 & 70.1 & 82.4 & 60.2 & 21.5 & 54.2 & 22.3 & 53.5 & 34.3 \\
\hline \multirow{5}{*}{ SGPT } & 24.6 & 26.3 & 62.4 & 71.2 & 68.3 & 17.2 & 71.9 & 20.1 & 75.2 & 26.2 \\
\hline & 29.2 & 31.4 & 58 & 78.8 & 73.2 & 25.3 & 69.8 & 28.3 & 60 & 19.3 \\
\hline & 30.1 & 32.6 & 59.5 & 69.2 & 69.6 & 21.3 & 59.2 & 31.2 & 63.4 & 20.1 \\
\hline & 18 & 22.3 & 70.1 & 81.9 & 72.4 & 19.6 & 81.3 & 45.2 & 71.3 & 18.3 \\
\hline & 15.6 & 18.7 & 68 & 85.6 & 68.6 & 20.4 & 90 & 48.2 & 78.6 & 21.3 \\
\hline \multirow{5}{*}{ Creatinine } & 0.48 & 0.52 & 1.54 & 1.72 & 1.59 & 0.92 & 1.61 & 1.33 & 1.77 & 1.53 \\
\hline & 0.53 & 0.58 & 1.63 & 1.69 & 1.63 & 1.11 & 1.67 & 1.3 & 1.64 & 1.49 \\
\hline & 0.61 & 0.63 & 1.62 & 1.82 & 1.57 & 0.72 & 1.73 & 1.52 & 1.58 & 1.24 \\
\hline & 0.42 & 0.69 & 1.58 & 1.92 & 1.88 & 0.69 & 1.59 & 1.1 & 1.91 & 1.31 \\
\hline & 1.12 & 1.15 & 1.42 & 1.78 & 1.92 & 1.23 & 1.79 & 1.58 & 1.62 & 0.62 \\
\hline
\end{tabular}




\section{International Journal of Cell Science \& Molecular Biology}

\begin{tabular}{|c|c|c|c|c|c|c|c|c|c|c|}
\hline \multirow{5}{*}{ Urea } & 30.2 & 31.2 & 86.7 & 91.2 & 75.2 & 23.2 & 69.3 & 38.4 & 78.3 & 41.2 \\
\hline & 29.2 & 30.4 & 40.4 & 94.2 & 77.6 & 26.2 & 72.5 & 40.1 & 77.9 & 38.3 \\
\hline & 24.6 & 25.6 & 73.8 & 80.1 & 68.3 & 19.4 & 77.9 & 44.6 & 66.1 & 29.4 \\
\hline & 28.2 & 26.2 & 78.4 & 86.6 & 88.7 & 31.4 & 82.3 & 50.3 & 81.5 & 50.2 \\
\hline & 22.3 & 24 & 93.4 & 98.3 & 90.2 & 35.3 & 73.4 & 39.2 & 69.8 & 30.4 \\
\hline \multirow{5}{*}{ HDL } & 40.1 & 35 & 21.2 & 15.2 & 30 & 40 & 17.6 & 21 & 18.4 & 26.4 \\
\hline & 35.8 & 40.3 & 20.2 & 12 & 20.1 & 41.3 & 21.3 & 29.4 & 23.7 & 29 \\
\hline & 34.4 & 41.7 & 18.9 & 10 & 18.6 & 35.3 & 24.6 & 30.4 & 21 & 29.4 \\
\hline & 35.3 & 38.5 & 19.2 & 12.2 & 15.2 & 36.2 & 20 & 28.6 & 39.4 & 45 \\
\hline & 41 & 36.2 & 30.2 & 18.1 & 20.2 & 38.1 & 19.2 & 24.6 & 28.3 & 36.4 \\
\hline \multirow{5}{*}{ LDL } & 22 & 24.7 & 58.8 & 62.3 & 58.4 & 25 & 66.8 & 42 & 59.7 & 31.2 \\
\hline & 30.2 & 32.3 & 60.2 & 71.4 & 56.4 & 24.8 & 62.8 & 45.1 & 55.8 & 36 \\
\hline & 24.4 & 20.2 & 65.4 & 69.2 & 68.3 & 29.4 & 72.1 & 56.3 & 60.3 & 34.6 \\
\hline & 28.6 & 29 & 71.2 & 76.7 & 67.7 & 20.4 & 75.6 & 60.1 & 71.7 & 50 \\
\hline & 23.4 & 30.4 & 80.4 & 80.4 & 60 & 25.4 & 68.3 & 52.4 & 67.8 & 38.4 \\
\hline
\end{tabular}

Table 10: Analysis of other Biochemical Parameters.

\begin{tabular}{|c|c|c|c|c|}
\hline Treatment & Dose & $\begin{array}{l}\text { Biochemical Parameter Maximum } \\
\text { Decreased from Day 0th to Day } 15^{\text {th }}\end{array}$ & $\%$ Decreased & Remarks \\
\hline \multirow{2}{*}{ PHF } & $200 \mathrm{mg} / \mathrm{kg}$ b. wt. & $\begin{array}{r}\text { SGOT } \\
\text { Urea } \\
\end{array}$ & $\begin{array}{r}57.2 \% \\
55.25 \%\end{array}$ & $\begin{array}{l}\text { Level of SGOT and urea level was found to be } \\
\text { remain constant. }\end{array}$ \\
\hline & $400 \mathrm{mg} / \mathrm{kg}$ b. wt. & $\begin{array}{c}\text { SGPT LDL } \\
\text { TC, TG, Creatinine }\end{array}$ & $\begin{array}{r}69.8 \% \\
39.60 \%\end{array}$ & $\begin{array}{l}\text { Decrease in SGPT is near to standard. Decrease in } \\
\text { creatinine level is greater than Std. }\end{array}$ \\
\hline
\end{tabular}

\section{Conclusion and Direction for Future Use}

Since Ancient times medicinal plants as single drug and in combination with other herbal drugs are using in the treatment of various chronic and non-chronic disorders. Ayurveda is one of the most traditional systems of medicine which describes the methodology to use the medicinal plants as healing power in treating the disease. Polyherbalism is also the best concept of Ayurveda, which consists of magical power of healing the disease. Ayurveda is one of the reliable and trustworthy medicine systems. In developing countries mostly $75-95 \%$ of populations rely on herbal drugs. Deep research and investigation still needed on this magical system of medicines. Research Studies pertaining to safety, toxicological studies, Standardization, clinical trial studies are still required to grow Ayurveda and increasing its wide acceptability. Numbers of commercialized standardized herbal drugs are quiet less in market since we are lacking in developing the regulatory standards implemented protocols. Diabetes mellitus has appearing as dreadful disorder for society. It directly impacts our metabolic system by making it sluggish in catabolic activities. It is mainly characterized by hyperglycaemia resulted from decrease insulin secretion. This dreadful disease can lead to many more complications like blindness, kidney failure and organ dysfunction. Several synthetic drugs are available in market but with long use of these drugs could lead to serious side effect including the kidney failure there is greater risk of using these synthetic drugs for long term. Study of ancient Ayurvedic books like Charak Samhita and Sushastra Samhita revealed that drugs used in Ayurvedic formulations worked synergistically on root cause of disease. Therefore, a quality control drug will be effective in management of diabetes. In view of above 3 plants, based on their reported mode of action PHF was made. PHF was subjected to acute toxicity study and found to be safe up to dose of $2000 \mathrm{mg} / \mathrm{kg}$ b.wt. After this oral glucose tolerance test (OGTT) was performed in animal model for preliminary assessment of antidiabetic activity. The antidiabetic activity was studied in albino wistar rats as per standard protocol. The diabetes was induced by use of Streptozotocin (STZ). For the study of antidiabetic activity PHF was given in 2 doses of $200 \mathrm{mg} / \mathrm{kg}$ b. wt and $400 \mathrm{mg} / \mathrm{kg}$ b.wt. for 14 days.The blood samples of each rat were analysed for various biochemical parameters. The results showed that PHF containing extracts of (Azadirecta indica, Moringa oeifera and Andrographis paniculata) showed significant antidiabetic and antihyperlipidemic activity which was close to standard drug. Along with remarkable reduction in Total Cholesterol (TC) level and increased in High Density Lipoprotein (HDL) STZ induced diabetes rats. The formulation has emerged as potential combination which can challenge the synthetic drug.

\section{References}

1. Shu YZ (1998) Recent natural products-based drug development: a pharmaceutical industry perspective. J nat prod 61(8): 1053-1071.

2. Thomson GM (2011) The naturalisation of animals and plants in New Zealand. Cambridge University Press, UK.

3. Sneader W (2005) Drug discovery: A history. John Wiley \& Sons, USA. 
4. Lewis WH, Elvin-Lewis MP (2003) Medical botany: plants affecting human health. John Wiley \& Sons, USA.

5. Lahlou M (2013) The success of natural products in drug discovery. Pharmacol Pharm 4(3A): 17-31.

6. Eckel RH, Grundy SM, Zimmet PZ (2005) The metabolic syndrome. The lancet. 365(9468): 1415-1428.

7. Grundy SM, Cleeman JI, Daniels SR, Donato KA, Eckel RH, et al. (2005) Diagnosis and management of the metabolic syndrome: an American Heart Association/National Heart, Lung, and Blood Institute scientific statement. Circulation 112(17): 2735-2752.

This work is licensed under Creative Commons Attribution 4.0 License

DOI: 10.19080/IJCSMB.2018.04.555656
8. Tataranni PA, Ortega E (2005) A burning question: does an adipokineinduced activation of the immune system mediate the effect of overnutrition on type 2 diabetes? Diabetes 54(4): 917-927.

9. Grundy SM (2004) Obesity, metabolic syndrome, and cardiovascular disease. The J Cli Endocrinol Metab 89(6): 2595-2600.

10. World Health Organization (1999) Definition, diagnosis and classification of diabetes mellitus and its complications: report of a WHO consultation. Part 1, Diagnosis and classification of diabetes mellitus. WHO, Geneva, Switzerland.

11. Care D (2000) Type 2 diabetes worldwide according to the new classification and criteria. Diabetes care 23(2): B5-B10.

\section{Your next submission with Juniper Publishers will reach you the below assets}

- Quality Editorial service

- Swift Peer Review

- Reprints availability

- E-prints Service

- Manuscript Podcast for convenient understanding

- Global attainment for your research

- Manuscript accessibility in different formats

( Pdf, E-pub, Full Text, Audio)

- Unceasing customer service

Track the below URL for one-step submission https://juniperpublishers.com/online-submission.php 